\title{
Alluvial rutile and anatase trace element geochemistry as a proxy for Sn and $W$ deposits
}

\author{
M. GASPAR ${ }^{1 *}$, N. GRÁCIO ${ }^{1}$ R. SALGUEIRO ${ }^{2}$ \\ ${ }^{1}$ GeoFCUL/IDL-FCUL, Campo Grande, Edifício C6, 1749- \\ 016 Lisboa, Portugal (*mgaspar@fc.ul.pt) \\ ${ }^{2}$ LNEG, Estrada da Portela, Bairro do Zambujal - Alfragide, \\ Apart. 7586, 2610-999 Amadora, Portugal
}

In Segura (East Central Portugal) several Sn-W quartz veins, and Li-Sn aplite-pegmatites, hosted in Paleozoic metasediments, are believed to be genetically related to the Variscan Segura Granitic Massif Alluvial samples from Segura area were studied to investigate its potential as an exploration tool for $\mathrm{Sn}$ and $\mathrm{W}$. The heavy mineral associations identified are a good proxy for the lithologies outcropping in each catchment area. Rutile abundance is positively correlated with both granites and orebodies, while anatase decreases along the granite contact or in mineralized areas, suggesting anatase to rutile transformation by high temperature and/or metasomatic processes.

Trace element geochemistry (EPMA) of Segura alluvial rutile and anatase is highly variable, acknowledging multiple sources and diversity of mineral forming processes. However, anomalous $\mathrm{Sn}, \mathrm{W}, \mathrm{Nb}, \mathrm{Ta}, \mathrm{Fe}$, and $\mathrm{V}$ enrichments are registered, more so in rutile than in anatase mainly due to crystal structure differences. Incorporation of traces follows isovalent substitution of $\mathrm{Sn}^{4+}$ for $\mathrm{Ti}^{4+}$ and the coupled substitution mechanisms $(\mathrm{Nb}, \mathrm{Ta})^{5+}+(\mathrm{Fe}, \mathrm{V})^{3+}=2 \mathrm{Ti}^{4+}, \mathrm{W}^{6+}+$ $2(\mathrm{Fe}, \mathrm{V})^{3+}=3 \mathrm{Ti}^{4+}$, and $\mathrm{W}^{6+}+\mathrm{Fe}^{2+}=2 \mathrm{Ti}^{4+}$. The highest values of $\mathrm{Nb}$ (up to $85000 \mathrm{ppm}$ ), W (up to $57000 \mathrm{ppm}$ ), Sn (up to $56000 \mathrm{ppm}$ ), $\mathrm{Fe}$ (up to 29000), Ta (up to $19000 \mathrm{ppm}$ ) and V (up to $11000 \mathrm{ppm}$ ) are registered in rutile from samples collected inside the granite, where a Sn-rich and a W-rich population can be distinguished. These HFSE-rich and granitophile-rich rutile grains most likely represent primary magmatic crystals of extremely differentiated melts thus, its occurrence in alluvial samples can be used to footprint Sn-W productive granitic rocks as the Segura Granite. Geochemical distribution maps of rutile and anatase trace element contents show pronounced negative Sn (rutile+anatase) and W (rutile) anomalies linked to hydrothermal cassiterite precipitation, as opposed to their hydrothermal alteration halos and to $\mathrm{W}$ dominant cassiterite-free mineralized areas, where primary hydrothermal rutile show similar enrichments to magmatic rutile, showing its potential as an exploration tool for $\mathrm{Sn}(\mathrm{W})$ and $\mathrm{W}(\mathrm{Sn})$ systems.

The authors acknowledge FCT financial support through project UIDB/50019/2020 - IDL; LNEG for alluvial samples. 